$\xi_{p}=$

\title{
Comparative study of efficacy of commercial anthelmintic response against gastrointestinal nematodes in goats of Jhenidah district, Bangladesh
}

\author{
Prodip Kumar Halder ${ }^{1,8 *}$, Biplob Kumar Sarker ${ }^{2,8}$, Md. Shah Alam ${ }^{7}$ Jannatun Nime ${ }^{3,8}$, Md. Tareq Mussa ${ }^{4,8}$, \\ Md. Mostafijur Rahman ${ }^{7}$, Bipul Kumer Chakraborty ${ }^{5}$, SM Harun-Ur-Rashid $^{6}$, \\ ${ }^{1}$ Department of Medicine \& Surgery \\ ${ }^{2}$ Department of Pathology and Parasitology \\ ${ }^{3}$ Department of Microbiology \\ ${ }^{4}$ Department of Anatomy and Histology \\ ${ }^{5}$ Upazilla Livestock Office Khansama, Bangladesh \\ ${ }^{6}$ Department of Pathology and Parasitology, Hajee Mohammad Danesh Science \& Technology University, Bangladesh \\ ${ }^{7}$ Department of Pathology and Parasitology, Patuakhali Science and Technology University, Bangladesh \\ ${ }^{8}$ Jhenidah Government Veterinary College, Bangladesh \\ *Corresponding author E-mail: pkhalder07@gmail.com
}

\begin{abstract}
Background: Parasitic disease constitutes $60-70 \%$ diseases affecting the animals and has serious economic implication in livestock entrepreneurship by direct and indirect production loss. Indiscriminate use of anthelmintic drugs has made the situation even more precarious. A similar problem was encountered in goat from Holidhani, Jhenidah, where goats with complain of intermittent diarrhea and loss of body condition was reported despite of routine deworming.

Objective: Determining the efficacy of conventional anthelmintics used and its comparison with some unexploited antiparasitic drugs for the same reason.

Methods: Sixty-five goats were divided into five groups. Group A goats were kept as the control, Group B (I, II, III), group C (IV, V, VI), group D (VII, VIII, IX) and group E (X, XI, XII) goats were treated with levamisole, albendazole, fenbendazole and ivermectin respectively All the treated and control goats were kept, housed for 21 days after the first treatment. Fecal samples were collected and counted on 1 st, 7th, 14th and 21st day by using McMaster counting method.

Results: Among the three doses of levamisole, albendazole, fenbendazole and ivermectin, the doses of 7.5, 7.5, $5.0 \mathrm{and} 0.2 \mathrm{mg} / \mathrm{kg}$ body weight, body weight were found to be most effective against gastrointestinal nematodes in goats with a maximum reduction of fecal egg count to the extent of $95.38,97.13,98.08 \& 99.16$ percent respectively.

Conclusion: The study revealed low efficacy of levamisole and hence ivermectin is a better drug than albendazole and fenbendazole to control gastrointestinal nematodes in goats.
\end{abstract}

Keywords: Parasitic Disease; Goat; Anthelmintic; Fecal Eggs and Efficacy.

\section{Introduction}

Bangladesh is one of the most densely populated country in the world with an estimated 1,033 people/km² (United Nations, 2011). Livestock density is also the highest in the world with an estimated 145 large ruminants $/ \mathrm{km}^{2}$ compared with 90 for India (BARC Bangladesh, 2010). It is estimated that 54.75 million of livestock in Bangladesh of which small ruminants constitute 29.33 millions of which goats 25.93 million and sheep 3.40 million (Livestock Economy, 2017). Goat is the second most important livestock of farmers in Bangladesh.

There are about 300 breeds and varieties of goats domesticated in Indian subcontinent. In Bangladesh, a native goat breed commonly known as Black Bengal goat, exotic breeds such as Sirohi, Beetal and Jamnapari and crossbreds between the Black Bengal goat and Jamnapari are found all over the country. Most of the goats in Bangladesh belongs to indigenous Black Bengal variety and the remaining are White Bengal and crosses of Jamunapari (Husain, 1993). Black Bengal goat is an interesting breed, which possesses a number of outstanding features. In addition, into its production of high-quality meat and world-famous skin, its fertility rate is higher, about $95 \%$, compared to other breeds in this subcontinent (Hasan et al., 2014).

Black Bengal Goat comprises more than $90 \%$ of the total goat population (Amin et al., 2001). The correlations between the number of goats per inhabitant and the mean income of the farmer are 0.77 and 0.52 respectively (Morand-Fehr and Boyazoglu, 1999), justifies the old saying "the goat is the poor man's cow" and is true for developing country like Bangladesh. Goat rearing plays very important role in rural economy and could be used as a tool for poverty reduction in Bangladesh. These animals are also important for good quality of meat, milk and leather. The goat ranks second in position in terms of meat, milk, and skin production, representing about 28,23 and 28 percent respectively of the total livestock in Bangladesh (FAO, 1999). The skin of goat of our country is world famous and play an important role 
in country's economy to earn foreign currency. Bangladesh earn 1.13 billion US dollar in the year of 2014-15 (Export Promotion Bureau, Bangladesh, 2014-15). Goat rearing plays the most important role for this purpose.

In Bangladesh, there are some constraints for goat rearing and production, among which various diseases and disorders of goat are the most important. Parasitism is the most important limiting factor of goat production in Bangladesh. It is established that infestations due to helminths undermine the health and productivity of goats. Asian Development Bank (ADB) report clearly mentioned the loss of productivity of animals in term of mortality, loss of milk, meat, generation loss and loss of reproductive rate due to animal parasite are to the extent of 50\% in Bangladesh. Undoubtedly, the geo-climatic condition of Bangladesh is suitable for growth, development and subsistence of various parasites (Hossain et al., 2004; Qadir, 1967; Haq and Shaikh, 1968). Several epidemiological studies have been carried out on gastrointestinal parasites of small ruminants in different regions of Bangladesh, which were affected by various intestinal helminths (Poddar et al., 2017; Sangma et al., 2012; Hassan et al., 2011; Islam and Taimur, 2008; Mohanta et al., 2007). In the torrid-zone, 60-95\% of sheep and goats had helminthiasis; of which, Haemonchus and Trichostrongylus were the two most commonly involved genera (Raza et al., 2014; Mbuh et al., 2008; Gathuma et al., 2007; Mondal et al., 2010). Sheep and goat are mainly reared for meat, wool and skin production (Hossain et al., 2004).

Extensive use of anthelmintics that too in inadequate dose has resulted in emergence of anthelmintic resistant strains of parasites (Silvestre et al., 2002 Wolstenholme et al., 2004). There are numerous reports of anthelmintic resistance from various parts of India (Ram et al., 2007; Buttar et al., 2012; Rialch et al., 2013). Khajuria (2010) has also reported the benzimidazole resistance in sheep and goats of Jammu. So, the objective of present study was to find out the comparative efficacy of levamisole, albendazole, fenbendazole and ivermectin against gastrointestinal nematodes in goats, maintained at Holidhani village, Jhenaidah district, Bangladesh based on fecal egg count reduction test.

\section{Materials and methods}

\subsection{Study area and study population}

The study was conducted at Holidhani, a village of Sadar Upazila of Jhenidah district, which is located near the campus of the Jhenidah Government Veterinary College, Jhenidah. Sixty-five goats were selected from Holidhani Village, in 30 households, of either sex weighing in a range of 20-25 kg body weight and age group between 2-3 years old. All goats were allowed to graze on pasture for about one month. After one month, they were housed with symptoms of intermittent diarrhea, poor body weight gain, anorexia and anemia.

\subsection{Sampling method and treatment}

All the goats were randomly divided into five groups. Group A containing 5 goats were kept as control without giving any treatment. Group B (sub-group I, II, III, each sub-group contains 5 goats) goats were treated with levamisole with the dose rate of $6.5,7.0,7.5 \mathrm{mg} / \mathrm{kg}$ body respectively; albendazole were administered to group C (sub-group IV, V, VI, each sub-group contains 5 goats) goats at the dose rate 6.5 , $7.0,7.5 \mathrm{mg} / \mathrm{kg}$ body weight respectively; group D (sub-group VII, VIII, IX, each sub-group contains 5 goats) goats were treated with fenbendazole at the dose rate of 4.0, 4.5, $5.0 \mathrm{mg} / \mathrm{kg}$ body weight respectively, group E (sub-group X, XI, XII, each sub-group contains 5 goats) goats were treated with ivermectin at the dose rate of $100 \mu \mathrm{g}, 150 \mu \mathrm{g}, 200 \mu \mathrm{g} / \mathrm{kg}$ body weight respectively. Prior to the start of the experimental trial, each goat was identified by ear tagging. The drugs Levamisole (Levavet Tablet), Albendazole (Benazol Tablet), Fenbendazole (Fenazole Vet Tablet) \& Ivermectin (A-Mectin Vet) were purchased from a veterinary drug store located in the study area (Holidhani Bazar, Jhenidah, Bangladesh).

\subsection{Fecal sample examination}

All the goats were kept under stall-fed condition during study period. Fecal samples were collected per rectum in air-tight bags and taken to the laboratory for analysis on $1^{\text {st }}$ (before drug administration), $7^{\text {th }}, 14^{\text {th }}$ and $21^{\text {st }}$ day. Fecal egg counts were carried out by the McMaster counting method (Soulsby 1986).

\subsection{Statistical analysis}

Fecal egg count reduction percentage was determined by using arithmetic mean count (Coles et al., 1992). Obtained data were analyzed by using online Student's t-test Comparison of two means. Student t-test was applied for testing the level of significance.

\section{RESULTS AND DISCUSSION}

\subsection{Levamisole (Levavet tablet)}

Oral administration of all the 3 doses $(6.5,7.0$ and $7.5 \mathrm{mg} / \mathrm{kg}$ body weight) of Levamisole significantly decreased the fecal egg count from $3^{\text {rd }}$ day onward of first treatment and continued till the $21^{\text {st }}$ day of treatment (Table 1). The reduction of fecal egg counts were $64.30,83.30$ and 95.38 percent following $(6.5,7.0$ and $7.5 \mathrm{mg} / \mathrm{kg}$ body weight) of Levamisole respectively (Table 1). More or less similar results were reported at a dose rate of $7.5 \mathrm{mg} / \mathrm{kg}$ body weight by Ali et al., (1997); Keyyu et al., (2002); Islam et al., (2015). On the other hand, Byaruhanga et al., (2013) reported a less efficacy (91\%) of levamisole against gastrointestinal nematodes in goats. But Godara et al., (2011) reported only $63.70 \%$ efficacy of levamisole against gastrointestinal nematodes in Jamunapari goats in India.

Table 1: Effect of Single Oral Administration of Levamisole (Levavet Tablet) Against Gastrointestinal Nematodes in Goats:

\begin{tabular}{|c|c|c|c|c|c|c|c|}
\hline $\begin{array}{l}\text { Group of ani- } \\
\text { mals }\end{array}$ & $\begin{array}{l}\text { Dose } \mathrm{mg} / \mathrm{kg} \text { body } \\
\text { weight }\end{array}$ & \multicolumn{5}{|c|}{ Time of feces collection (day) } & $\begin{array}{l}\text { Maximum rate of reduc- } \\
\text { tion }\end{array}$ \\
\hline \multirow[t]{2}{*}{ A } & Control & $\begin{array}{l}2469 \\
\pm 62.0\end{array}$ & $2470 \pm 78.4$ & $2485 \pm 69.7$ & $2489 \pm 45.7$ & $\begin{array}{l}2514 * \\
\pm 39.4\end{array}$ & 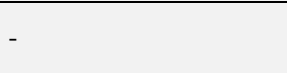 \\
\hline & 6.5 & $\begin{array}{l}2381 \\
\pm 98.4\end{array}$ & $\begin{array}{l}1073 * * \\
\pm 59.5\end{array}$ & $\begin{array}{l}932 * * \\
\pm 58.6\end{array}$ & $\begin{array}{l}894 * * \\
\pm 43.0\end{array}$ & $\begin{array}{l}850 * * \\
\pm 85.8\end{array}$ & $64.30 \%$ \\
\hline
\end{tabular}




\begin{tabular}{|c|c|c|c|c|c|c|c|}
\hline \multirow[t]{2}{*}{ B } & 7.0 & $\begin{array}{l}2527 \\
\pm 70.9\end{array}$ & $748 * * \pm 49.3$ & $\begin{array}{l}626^{* * *} \\
\pm 58.1\end{array}$ & $\begin{array}{l}534 * * \\
\pm 48.9\end{array}$ & $\begin{array}{l}422 * * \\
\pm 54.7\end{array}$ & $83.30 \%$ \\
\hline & 7.5 & $\begin{array}{l}2188 \\
\pm 64.3\end{array}$ & $430 * * \pm 51.5$ & $\begin{array}{l}184 * * \\
\pm 47.4\end{array}$ & $\begin{array}{l}109 * * \\
\pm 23.7\end{array}$ & $\begin{array}{l}101 * * \\
\pm 15.4\end{array}$ & $95.38 \%$ \\
\hline
\end{tabular}

Values given above represent the mean $\pm \mathrm{SE}$ of 5 goats. * Significant decrease $(\mathrm{P}<0.05)$, ** Significant decrease $(\mathrm{P}<0.01)$.

\subsection{Albendazole (Benazol tablet)}

Oral administration of all the 3 doses $(6.5,7.0$ and $7.5 \mathrm{mg} / \mathrm{kg}$ body weight) of Albendazole significantly decreased the fecal egg count from $3^{\text {rd }}$ day onward of first treatment and continued till the $21^{\text {st }}$ day of treatment (Table 2). The percentage of reduction of egg count were 65.83 , $84.11 \& 97.13$ percent following (6.5, 7.0 and $7.5 \mathrm{mg} / \mathrm{kg}$ body weight) of Albendazole (Table 2). More or less similar results were reported at a dose rate of $7.5 \mathrm{mg} / \mathrm{kg}$ body weight by Sakhawat Ali et al., (1997); Oyeduntan et al., (2015); Rexford Pinkrah, (2017). Tsegaye Teklemariam et al., (2016), Akhter et al., (2016) reported 95\% efficacy of albendazole against gastrointestinal nematodes in goats. Islam et al., (2015), reported $84.44 \%$ efficacy of Albendazole against gastrointestinal nematodes in goats. On the other hand, Ram et al., (2007), Byaruhanga (2013) \& reported only $14 \& 28.5 \%$ efficacy of Albendazole respectively in albendazole resistant goats.

Table 2: Effect of Single Oral Administration of Albendazole (Benazol Tablet) Against Gastrointestinal Nematodes in Goats:

\begin{tabular}{|c|c|c|c|c|c|c|c|}
\hline \multirow{2}{*}{$\begin{array}{l}\text { Group of ani- } \\
\text { mals }\end{array}$} & \multirow{2}{*}{$\begin{array}{l}\text { Dose } \mathrm{mg} / \mathrm{kg} \text { body } \\
\text { weight }\end{array}$} & \multicolumn{5}{|c|}{ Time of feces collection (day) } & \multirow{2}{*}{$\begin{array}{l}\text { Maximum rate of reduc } \\
\text { tion }\end{array}$} \\
\hline & & $1^{\text {st }}$ & $3^{\text {rd }}$ & $7^{\text {th }}$ & $14^{\text {th }}$ & $21^{\mathrm{st}}$ & \\
\hline \multirow[t]{2}{*}{ A } & Control & $\begin{array}{l}2469 \\
\pm 62.0\end{array}$ & $2470 \pm 78.4$ & $2485 \pm 69.7$ & $2489 \pm 45.7$ & $\begin{array}{l}2514^{*} \\
\pm 39.4\end{array}$ & ( \\
\hline & 6.5 & $\begin{array}{l}2066 \\
\pm 61.6\end{array}$ & $\begin{array}{l}857 * * \\
\pm 51.52\end{array}$ & $\begin{array}{l}785 * * \\
\pm 74.4\end{array}$ & $\begin{array}{l}753 * * \\
\pm 36.82\end{array}$ & $\begin{array}{l}706 * * \\
\pm 49.2\end{array}$ & $65.83 \%$ \\
\hline \multirow{2}{*}{$\mathrm{C}$} & 7.0 & $\begin{array}{l}1995 \\
\pm 73.5\end{array}$ & $561 * * \pm 55.4$ & $\begin{array}{l}458 * * \\
\pm 42.7\end{array}$ & $385^{* *} \pm 39.7$ & $\begin{array}{l}317 * * \\
\pm 44.8\end{array}$ & $84.11 \%$ \\
\hline & 7.5 & $\begin{array}{l}2128 \\
\pm 58.3 \\
\end{array}$ & $380 * * \pm 52.0$ & $\begin{array}{l}169 * * \\
\pm 29.7 \\
\end{array}$ & $123 * * \pm 22.9$ & $61 * * \pm 17.1$ & $97.13 \%$ \\
\hline
\end{tabular}

Values given above represent the mean \pm SE of 5 goats. * Significant decrease $(\mathrm{P}<0.05)$, ** Significant decrease $(\mathrm{P}<0.01)$

\subsection{Fenbendazole (Fenazole vet tablet):}

Oral administration of all the three doses (4.0, 4.5 and $5.0 \mathrm{mg} / \mathrm{kg}$ body weight) of Fenbendazole significantly decreased the fecal egg count from $3^{\text {rd }}$ day onward of first treatment and continued till the $21^{\text {st }}$ day of treatment (Table 5). The reduction of fecal egg counts were 66.11, $85.17 \& 98.08$ percent following (4.0, 4.5 and $5.0 \mathrm{mg} / \mathrm{kg}$ body weight) of Fenbendazole respectively (Table 3). More or less similar results were reported at a dose rate of $5.0 \mathrm{mg} / \mathrm{kg}$ body weight by Kennedy TJ et al., (1975); P. Sharma et al., (2014); S.R. Tramboo et al., (2017). On the other hand, Sharma et al., (2015) reported $70.87 \%$ on $14^{\text {th }}$ day; Islam et al., (2015) reported $93.93 \%$ efficacy of fenbendazole against gastrointestinal nematodes in sheep and goats. But Godara et al., (2011) reported only $23.66 \%$ efficacy of fenbendazole against gastrointestinal nematodes in Jamnapari goats in India.

Table 3: Effect of Single Oral Administration of Fenbendazole (Fenazole Vet Tablet) Against Gastrointestinal Nematodes in Goats:

\begin{tabular}{|c|c|c|c|c|c|c|c|}
\hline \multirow{2}{*}{1} & \multirow{2}{*}{ Dose $\mathrm{mg} / \mathrm{kg}$ body weight } & \multicolumn{5}{|c|}{ Time of feces collection (day) } & \multirow{2}{*}{ Maximum rate of reduction } \\
\hline & & $1^{\text {st }}$ & $3^{\text {rd }}$ & $7^{\text {th }}$ & $14^{\text {th }}$ & $21^{\mathrm{st}}$ & \\
\hline \multirow[t]{3}{*}{ A } & Control & $2469 \pm 62.0$ & $2470 \pm 78.4$ & $2485 \pm 69.7$ & $2489 \pm 45.7$ & $2514 * \pm 39.4$ & - \\
\hline & 4.0 & $1989 \pm 70.6$ & $874 * * \pm 31.7$ & $733 * * \pm 45.9$ & $721 * * \pm 28.6$ & $674 * * \pm 43.7$ & $66.11 \%$ \\
\hline & 4.5 & $1868 \pm 50.6$ & $521 * * \pm 37.1$ & $460 * * \pm 36.6$ & $353^{* *} \pm 38.6$ & $277 * * \pm 50.6$ & $85.17 \%$ \\
\hline $\mathrm{D}$ & 5.0 & $2139 \pm 77.3$ & $361 * * \pm 38.7$ & $149 * * \pm 35.3$ & $86^{* *} \pm 11.5$ & $41 * * \pm 15.7$ & $98.08 \%$ \\
\hline
\end{tabular}

Values given above represent the mean \pm SE of 5 goats. * Significant decrease $(\mathrm{P}<0.05)$, ** Significant decrease $(\mathrm{P}<0.01)$.

\subsection{Ivermectin (A-Mectin vet)}

Sub-cutaneous injection of all the 3 doses $(0.10,0.15$ and $0.20 \mathrm{mg} / \mathrm{kg}$ body weight) of Ivermectin (A-Mectin Vet) significantly decreased the fecal egg count from $3^{\text {rd }}$ day onward of first treatment and continued till the $21^{\text {st }}$ day of treatment (Table 4$)$. The reduction of fecal egg counts was $63.11,81.03$ and 99.16 percent following $(0.1,0.15$ and $0.2 \mathrm{mg} / \mathrm{kg}$ body weight) of Ivermectin respectively (Table 4$)$. Ali et al., (1997) reported 97.02\%; Ram et al., (2007) reported 96\%; Godara et al., (2011) reported 98.11\%; Byaruhanga et al., (2013) reported 98\%; Sharma et al., (2015) reported 100\%; Teklemariam et al., (2016) reported 99\%; S. K. Tramboo et al., (2017) reported 98.80\% efficacy of ivermectin against gastrointestinal nematodes in sheep and goats.

Table 4: Effect of Single Sub-Cutaneous Administration of Ivermectin (A-Mectin Vet) Against Gastrointestinal Nematodes in Goats

\begin{tabular}{|c|c|c|c|c|c|c|c|}
\hline \multirow{2}{*}{$\begin{array}{l}\text { Group of ani- } \\
\text { mals }\end{array}$} & \multirow{2}{*}{$\begin{array}{l}\text { Dose } \mathrm{mg} / \mathrm{kg} \text { body } \\
\text { weight }\end{array}$} & \multicolumn{5}{|c|}{ Time of feces collection (day) } & \multirow{2}{*}{$\begin{array}{l}\text { Maximum rate of reduc- } \\
\text { tion }\end{array}$} \\
\hline & & $1^{\mathrm{st}}$ & $3^{\text {rd }}$ & $7^{\text {th }}$ & $14^{\text {th }}$ & $21^{\text {st }}$ & \\
\hline A & Control & $2469 \pm 62.0$ & $2470 \pm 78.4$ & $2485 \pm 69.7$ & $2489 \pm 45.7$ & $\begin{array}{l}2514 * \\
\pm 39.4\end{array}$ & - \\
\hline \multirow{3}{*}{$\mathrm{E}$} & 0.10 & $1884 \pm 63.9$ & $\begin{array}{l}957 * * \\
\pm 60.0\end{array}$ & $\begin{array}{l}792 * * \\
\pm 78.0\end{array}$ & $\begin{array}{l}734 * * \\
\pm 34.4\end{array}$ & $\begin{array}{l}696 * * \\
\pm 31.0\end{array}$ & $63.11 \%$ \\
\hline & 0.15 & $1924 \pm 97.6$ & $\begin{array}{l}614 * * \\
\pm 67.9\end{array}$ & $\begin{array}{l}519 * * \\
\pm 29.3\end{array}$ & $\begin{array}{l}403 * * \\
\pm 40.5\end{array}$ & $\begin{array}{l}365 * * \\
\pm 53.0\end{array}$ & $81.03 \%$ \\
\hline & 0.2 & $\begin{array}{l}2264 \\
\pm 131.0\end{array}$ & $\begin{array}{l}293 * * \\
\pm 64.3\end{array}$ & $\begin{array}{l}112 * * \\
\pm 17.1\end{array}$ & $42 * * \pm 13.5$ & $19 * * \pm 6.2$ & $99.16 \%$ \\
\hline
\end{tabular}

Values given above represent the mean \pm SE of 5 goats. * Significant decrease $(\mathrm{P}<0.05)$, ** Significant decrease $(\mathrm{P}<0.01)$.

\subsection{Comparative efficacy of four anthelmintics}


Among the three doses of Levamisole (6.5, $7.0 \& 7.5 \mathrm{mg} / \mathrm{kg}$ body weight), Albendazole (6.5, $7.0 \& 7.5 \mathrm{mg} / \mathrm{kg}$ body weight), Fenbendazole $(4.4,4.5 \& 5.0 \mathrm{mg} / \mathrm{kg}$ body weight) \& Ivermectin $(0.1,0.15 \& 0.2 \mathrm{mg} / \mathrm{kg}$ body weight), the most effective dosage of Levamisole is 7.5 $\mathrm{mg} / \mathrm{kg}$ body weight, that of Albendazole is $7.5 \mathrm{mg} / \mathrm{kg}$ body weight, that of Fenbendazole is $5 \mathrm{mg} / \mathrm{kg}$ body weight and that of Ivermectin is $0.2 \mathrm{mg} / \mathrm{kg}$ body weight (Table $1,2,3 \& 4$ ).

It is evident that levamisole, albendazole, fenbendazole and ivermectin reduced the fecal egg count up to 95.38, 97.13, 98.08 \& 99.16 percent respectively in goats (Table 5). Among four anthelmintics, ivermectin was the most effective (Fecal egg count reduction was $99.16 \%$ ) and levamisole was the least effective (Fecal egg count reduction was $95.38 \%$ ).

Table 5: Comparative Efficacy of Oral Administration of Levamisole, Albendazole, Fenbendazole \& Sub-Cutaneous Administration of Ivermectin against Gastrointestinal Nematodes in Goats

\begin{tabular}{|c|c|c|c|c|c|c|c|c|}
\hline \multirow{2}{*}{$\begin{array}{l}\text { Group of ani- } \\
\text { mals }\end{array}$} & \multirow[b]{2}{*}{ Name of drug } & \multirow{2}{*}{$\begin{array}{l}\text { Dos mg/kg } \\
\text { body } \\
\text { weight }\end{array}$} & \multicolumn{5}{|c|}{ Time of feces collection (day) } & \multirow{2}{*}{$\begin{array}{l}\text { Maximum rate } \\
\text { of reduction }\end{array}$} \\
\hline & & & $1^{\text {st }}$ & $3^{\text {rd }}$ & $7^{\text {th }}$ & $14^{\text {th }}$ & $21^{\mathrm{st}}$ & \\
\hline A & - & Control & $2469 \pm 62.0$ & $2470 \pm 78.4$ & $2485 \pm 69.7$ & $2489 \pm 45.7$ & $\begin{array}{l}2514^{*} \\
\pm 39.4\end{array}$ & - \\
\hline B & Levamisole & 7.5 & $2188 \pm 93.3$ & $\begin{array}{l}430 * * \\
\pm 85.0\end{array}$ & $\begin{array}{l}184 * * \\
\pm 32.9\end{array}$ & $\begin{array}{l}109 * * \\
\pm 15.1\end{array}$ & $\begin{array}{l}101 * * \\
\pm 12.3\end{array}$ & $95.38 \%$ \\
\hline $\mathrm{C}$ & Albendazole & 7.5 & $2128 \pm 58.3$ & $\begin{array}{l}380 * * \\
\pm 52.0\end{array}$ & $\begin{array}{l}169 * * \\
\pm 29.7\end{array}$ & $\begin{array}{l}123 * * \\
\pm 22.9\end{array}$ & $61 * * \pm 17.1$ & $97.13 \%$ \\
\hline $\mathrm{D}$ & Fenbendazole & 5.0 & $2139 \pm 77.3$ & $\begin{array}{l}361 * * \\
\pm 38.7\end{array}$ & $\begin{array}{l}149 * * \\
\pm 35.3\end{array}$ & $86^{* *} \pm 11.5$ & $41 * * \pm 15.7$ & $98.08 \%$ \\
\hline E & Ivermectin & 0.2 & $\begin{array}{l}2264 \\
\pm 131.0\end{array}$ & $\begin{array}{l}293 * * \\
\pm 64.3 \\
\end{array}$ & $\begin{array}{l}112 * * \\
\pm 17.1\end{array}$ & $42 * * \pm 13.5$ & $19 * * \pm 6.2$ & $99.16 \%$ \\
\hline
\end{tabular}

Values given above represent the mean \pm SE of 5 goats. * Significant decrease $(\mathrm{P}<0.05), * *$ Significant decrease $(\mathrm{P}<0.01)$.

\section{Conclusion}

The study has shown that all four anthelmintics used in this study were effective to reduce the fecal egg count significantly against gastrointestinal nematodes in goats in Holidhani, Jhenidah district. Strategies recommended to control helminths include a better use of existing drugs, use of vaccines for helminths, growth regulators, and biological control. Further studies, however, are needed to assess the efficacy status of levamisole, albendazole, fenbendazole and ivermectin in different animal species, and management systems.

\section{References}

[1] Akhter N, Mirbahar KB, Jatoi SA, Bhutto B \& Mirani AH (2016) Efficacy of Valbazen (Albendazole) against gastrointestinal Nematodes in goats. Pakistan Journal of Agriculture, Agricultural Engineer and Veterinary Science 32 (2): 277-283.

[2] Ali S, Anwar AH, Hayat B, Iqbal Z \& Hayat CS (1997) Field Evaluation of Anthelmintic Efficacy of Levamisole, Albendazole, Ivermectin and Morantel Tartrate against gastrointestinal nematodes of sheep. Pakistan Veterinary 17 (3).

[3] Amin MR, Husain SS \& Islam ABMM (2001) Reproductive peculiarities and litter weight in different genetic groups of Black Bengal does. AsianAustralian Journal of Animal Science 14(3): 297-301.

[4] BARC Bangladesh (2010). Agricultural Research Priority: Vision-2030 and Beyond (Sub-sector: Livestock). Bangladesh Agriculture Research Council, Farmgate, Dhaka.

[5] Buttar BS, Rai HS, Singh NK, Jyoti HM \& Rath S (2012) Emergence of anthelminthic resistance in an organized sheep farm in Punjab. Journal of Veterinary Parasitology 26(1):69-71.

[6] Byaruhanga C \& Okwee-Acai J (2013) Efficacy of albendazole, levamisole and ivermectin against gastro-intestinal nematodes in naturally infected goats at the National Semi-arid Resources Research Institute, Serere, Uganda. Veterinary Parasitology. Volume 195. Issue 1-2, 183-186. https://doi.org/10.1016/j.vetpar.2013.01.007.

[7] Coles GC, Bauer C, Borgsteede FHM, Greats S, Klei TR \& Taylor MA (1992) World Association for the Advancement of Veterinary Parasitology (WAAVP) methods for the detection of anthelmintic resistance in nematodes of veterinary importance. Vet. Parasitol., 44: 35- 44. https://doi.org/10.1016/0304-4017(92)90141-U.

[8] FAO (1999) Opportunities for incorporating genetic elements into the management of farm animal diseases: policy issues, by S. Bishop, M. de Jong \& D. Gray. Background Study Paper No. 18. Commission on Genetic Resources for Food and Agriculture. Rome (available at $\mathrm{ftp}: / / \mathrm{ftp}$. fao.org/docrep/fao /meeting /015/aj629e. pdf).

[9] Gathuma J, Gachuiri M \& Omore A (2007) Risk factors of gastrointestinal nematode parasite infections in small ruminants kept in smallholder mixed farms in Kenya. BMC Veterinary Research 3:1. https://doi.org/10.1186/1746-6148-3-1.

[10] Godara R, Sharma RL \& Sodhi SS (2011) Efficacy of fenbendazole, levamisole and ivermectin against gastrointestinal nematodes in Jamunapari goats. Journal of Parasitic Diseases 35(2):219-21. https://doi.org/10.1007/s12639-011-0052-5.

[11] Haq S \& Shaikh H (1968) A Survey of Helminth Parasitsing the Gastro-intestinal Tracts of Goats and Sheep in East Pakistan. East Pakistan Journal of Veterinary Science 2(2): 54-62.

[12] Hasan MJ, Ahmed JU \& Alam MM (2014) Reproductive performances of Black Bengal goat under semi intensive and extensive conditions at rural areas in Bangladesh. Journal of Advance in Veterinary and Animal Research 1(4): 196-200. https://doi.org/10.5455/javar.2014.a37.

[13] Hassan MM, Hoque MA, Islam SKMA, Khan SA, Roy K, Banu Q. A (2011) prevalence of parasites in Black Bengal goats in Chittagong, Bangladesh. International Journal of Livestock Production 2:40-44.

[14] Hossain MJ, Amin M, Mostofa M, Sharif Khalid SMA (2004). Efficacy of levanid against natural gastrointestinal nematodiasis and paramphistomiasis in sheep. Bangladesh Veterinary Journal 21:70-73.

[15] Husain SS (1993) A study on the productive performance and genetic potentials of Black Bengal goats. A Ph.D. Thesis, Bangladesh Agricultural University, Mymensingh.

[16] Islam KB \& Taimur MJFA (2008). Helminthic and protozoan internal parasitic infections in free ranging small ruminants of Bangladesh. Slovenian Veterinary Researcher 45: 67-72.

[17] Islam MM, Islam MA, Rahman MM, Howlader \& Lucky N (2015) Prevalence of Gastrointestinal Nematodiasis and Comparative Efficacy of Anthelmintics on Body Weight of Cattle in Bangladesh. International Journal of Scientific Research in Agricultural Sciences 2(3): 061-075. https://doi.org/10.12983/ijsras-2015-p0061-0075.

[18] Kennedy TJ \& Todd AC (1975) Efficacy of Fenbendazole against gastrointestinal parasites of sheep. American Journal of Veterinary Research 36(10): 1465-7.

[19] Keyyu JD, Mahingika HM, Magwisha HB \& Kassuku AA (2002) Efficacy of Albendazole and Levamisole against Gastrointestinal Nematodes of Sheep and Goats in Morogoro, Tanzania. Tropical Animal Health and Production 34(2): 115-120. https://doi.org/10.1023/A:1014214122167. 
[20] Khajuria JK (2010) Studies on epidemiology and resistance against benzimidazoles in gastrointestinal nematodes of small ruminants, PhD thesis submitted to SKUAST-J, Jammu, 1-69.

[21] Livestock Economy (2017) Department of Livestock Services, Bangladesh.

[22] Mbuh JV, Ndamukong KJ, Ntonifor N \& Nforlem GF (2008) Parasites of sheep and goats and their prevalence in Bokova, a rural area of Buea Sub Division, Cameroon. Veterinary Parasitology 156:350-352. https://doi.org/10.1016/j.vetpar.2008.06.021.

[23] Mohanta UK, Anisuzzaman A, Farjana T, Das PM, Majumder S and Mondal MMH (2007) Prevalence, population dynamics and pathological effects of intestinal helminths in Black Bengal goats. Bangladesh Journal of Veterinary Medicine 5:63-69. https://doi.org/10.3329/bjvm.v5i1.1313.

[24] Mondal MMH, Islam MK, Hur J, Lee JH \& Baek BK (2010) Examination of gastrointestinal helminth in livestock grazing in grassland of Bangladesh. The Korean Journal of Parasitology 38:187-190. https://doi.org/10.3347/kjp.2000.38.3.187.

[25] Morand-Fehr P \& Boyazoglu J (1999) Present state and future look of the small ruminant sector. Small Ruminant Research 34:175-188. https://doi.org/10.1016/S0921-4488(99)00071-1.

[26] Oyeduntan A \& Uwalaka EC (2015) Effectiveness Evaluation of Levamisole, Albendazole, Ivermectin, and Vernonia amygdalina in West African Dwarf Goats. Journal of Parasitology Research Volume. Article ID 706824, 5 pages. https://doi.org/10.1155/2015/706824.

[27] Pinkrah R (2017) The efficacy of Albendazole against gastrointestinal nematodes in naturally Infected sheep and goats on three different farming systems in Ghana. Research · November 2017

[28] Poddar PR, Begum N, Alim MA, Dey AR, Hossain MS \& Labony SS (2017) Prevalence of gastrointestinal helminths of sheep in Sherpur, Bangladesh. Journal of Advanced Veterinary and Animal Research. 4:274-280. https://doi.org/10.5455/javar.2017.d224.

[29] Qadir ANMA (1967) Investigation on the incidence of gastrointestinal parasites of goats in the East Pakistan Agricultural University Campus. Bangladesh Veterinary Journal 15(2): 58-61.

[30] Ram H, Rasool TJ, Sharma AK, Meena HR \& Singh SK (2007) Comparative efficacy of different anthelmintics against fenbendazole resistant nematodes of pashmina goats. Veterinary Research and Communication 31: 719-723. https://doi.org/10.1007/s11259-007-0021-8.

[31] Raza MA, Younas M \& Schlecht E (2014) Prevalence of gastrointestinal helminths in pastoral sheep and goat flocks in the Cholistan desert of Pakistan. The Journal of Animal \& Plant Sciences. 24:127- 134.

[32] Rialch A, Vatsya S \& Kumar RR (2013) Detection of benzimidazole resistance in gastrointestinal nematodes of sheep and goats of sub himalyan region of northern India using different tests. Veterinary Parasitology 198: 312-318. https://doi.org/10.1016/j.vetpar.2013.09.018.

[33] Tramboo SR, Shasardar RA, Allaie IM, Wani ZA \& Abbas M (2017) Efficacy of ivermectin, closantel and fenbendazole against gastrointestinal nematodes of sheep in Kashmir valley. Journal of Parasitic Diseases 4(2): 380-382. https://doi.org/10.1007/s12639-016-0810-5.

[34] Sangma A, Begum N, Roy BC \& Gani MO (2012) Prevalence of helminth parasites in sheep (Ovis aries) in Tangail district, Bangladesh. Journal of the Bangladesh Agricultural University 10: 235-244. https://doi.org/10.3329/jbau.v10i2.14913.

[35] Sharma P, Sharma D, Dogra PK \& Mandial RK (2014) Comparative efficacy of fenbendazole and oxyclozanide-tetramisole combination against gastrointestinal nematodes in naturally infected Gaddi goats. Veterinary Research International 2(1): 15-17.

[36] Sharma S, Kumar S, Farooq J \& Katoch R (2015) Comparative Study of Efficacy of Fenbendazole and Ivermectin against Haemonchus contortus in Goats of Jammu region. Journal of Animal Research 5(2): 293-295. https://doi.org/10.5958/2277-940X.2015.00050.9.

[37] Silvestre A, Leignel V, Berrag B, Gasnier N, Humbert JF, Chartiere C \& Cabaret J (2002) Sheep and goat nematode resistance to anthelmintics: pros and cons among breeding management factors. Veterinary Research 33: 465-80. https://doi.org/10.1051/vetres:2002033.

[38] Teklemariam T, Fantahun T, Alemayehu B \& Beyene A (2016). Efficacy of selected anthelmintics against gastrointestinal nematodes on naturally infected small ruminants in Gimbo district, Kaffa Zone, South West Ethiopia. Livestock Research for Rural Development, 28 (12).

[39] United Nations (2011). Department of Economic and Social Affairs, Population Divition: World population Prospects: The 2010 Revision. New York.

[40] Wolstenholme AJ, Fairweather I, Prichard R \& Samson V (2004) Drug resistance in veterinary helminthes. Trends in Parasitology 20:469-476. https://doi.org/10.1016/j.pt.2004.07.010. 